\title{
TAHU SEBAGAI ANDALAN INDUSTRI PARIWISATA DI SUMEDANG
}

\author{
Oleh : Dadang Sungkawa*)
}

\begin{abstract}
Abstrak
Bila kita berbicara Kabupaten Sumedang maka yang terlintas dalam pikiran kita adalah tahu Sumedang yang merupakan makanan khas dari kota ini. Setiap orang mulai dari anak - anak hingga orang tua suka dengan tahu sebagai makanan yang banyak mengandung protein. Tahu bisa dimakan bersama nasi atau sebagai makanan cemilan dalam perjalanan di kendaraan atau sebagai oleh - leh apabila dibawa ke rumah atau tempat tujuan. Tahu Sumedang berbeda dengan tahu - tahu yang dibuat di tempat lain di Jawa Barat karena memiliki rasa khas yang empuk, enak, dan gurih. Perbedaan rasa tahu inilah yang menyebabkan Sumedang sebagai kota atau daerah tahu. Perkembangan industri tahu di Sumedang ini berdampak positif terhadap kemajuan ekonomi masyarakat Sumedang.

Kata kunci: Industri, Pariwisata.
\end{abstract}

*) Drs. Dadang Sungkawa, M.Pd adalah dosen Jurusan Pendidikan Geografi FPIPS UPI 


\section{Pendahuluan}

Kabupaten Sumedang merupakan wilayah yang dilalui oleh jalur lalu -lintas antara dua kota yaitu Bandung dan Cirebon. Kendaraan yang melalui daerah ini tiap harinya sangat padat baik kendaraan pribadi maupun kendaraan umum, khususnya kendaar besar seperti bus dan truk, yang bukan hanya tujuan Cirebon, namun banyak juga yang menuju Tegal, Pekalongan dan Purwokerto. Bila kita naik kendaraan pribadi atau kendaraan umum dari Bandung menuju Cirebon, maka apabila memasuki wilayah Sumedang kita akan menemui banyak PTS (=Pedagang Tahu Sumedang) baik yang berada di pinggir - pinggir jalan seperti kios - kios dan toko tahu maupun para pedagang asongan yang menjajakan tahu di dalam bus - bus jurusan Cirebon.

Perdagangan tahu di Wilayah Sumedang nampaknya makin lama makin berkembang,hal ini dapat di lihat dari bertambahnya para PTS yang menjajakan barangnya diluar Sumedang, seperti di Cileunyi dan Cicalengka atau daerah Kadipaten. Begitu populernya tahu Sumedang ini sekarang makanan ini bisa dibeli di luar Kabupaten Sumedang karena banyak PTS dari luar Sumedang yang mengadu untung dengan berjualan tahu.

Selain tahu andalan barang dagangan lainnya dari Sumedang adalah sawo yang sepanjang tahun dipasarkan di sepanjang jalan legok oleh para WTS (= Wanita Tukang Sawo ). Sawo dari daerah ini selalu ada sepanjang tahun karena sawo di daerah ini berbuah terus menerus tidak ditentukan oleh musim. Sawo dari jalan legok ini juga menjadi barang dagangan pariwisata sebagai oleh - oleh bagi orang - orang yang melewati wilayah ini.

\section{Faktor historis dan geografis yang mendukung eksistensi industri tahu di Kabupaten Sumedang}

Secara historis diketahui bahwa tahu pertama kali dibuat di Cina sekitar tahun 200 SM, dengan tidak sengaja. Pembuatan tahu pertama kali diperkenalkan oleh Liu An pada tahun 164 SM, pada zaman 
pemerintahan Dinasti Han. Selanjutnya pembuatan tahu disebarkan ke berbagai negara termasuk Indonesia oleh para biksu sambil mengajarkan agama Budha. Kata tahu berasal dari bahasa Cina yaitu Tao - hu atau Teu - hu. Teu artinya kedelai dan hu artinya lumat atau menjadi bubur, jadi tahu adalah kedelai yang dilumatkan atau dibuat bubur.

Tahu Sumedang pertama kali dibuat oleh Emigran dari Cina yang bernama Ong Kin No pada tahun 1900-an. Kelezatan tahu yang dibuatnya menarik perhatian pangeran sumedang untuk datang ke rumahnya di kawasan pusat kota Sumedang. Sejak saat itu tahu buatan Ong Kin No mulai dikenal orang. Sejak itu Ong Kin No menjadi pembuat dan penjual tahu.

Tahu Sumedang lebih berkembang dengan pesat setelah ditangani oleh putra Ong Kin No yaitu Ong Bung Keng. Tahu buatannya dikenal dengan nama tahu Bung Keng. Tahu Bung Keng sekarang dikelola oleh generasi keempat dan berkembang bukan hanya di Sumedang tetapi juga di Jawa Barat. Tahu Sumedang mempunyai keunikan sendiri dibandingkan dengan jenis tahu lainnya seperti rasanya yang gurih dan mempunyai kulit luar yang berbintik - bintik.

Faktor geografis yang mendukung keberadaan industri tahu di Sumedang berdasarkan penelitian Tati Sumiati (2007 : 69) adalah mudah memperoleh bahan mentah, tersedianya tenaga kerja dan dekat dengan tempat pemasaran sehingga industri tahu ini cukup menguntungkan bagi para pengusaha. Bahan baku utama pembuatan tahu adalah kacang kedelai sedangkan bahan penunjang lainnya adalah air, penggumpal (koagulan), anti busa, pengawet, minyak goreng dan bumbu. Kacang kedelai mudah diperoleh di Sumedang, baik kacang kedelai lokal (berbiji kecil dan berwarna kuning) maupun kacang kedelai impor (berbiji besar, berbentuk bulat dan warnanya putih) yang bisa diperoleh dari pasar atau koperasi tahu dan tempe. Pada umumnya pembuat tahu di Sumedang lebih suka memilih kacang kedelai lokal karena hasilnya lebih banyak dan rasanya gurih dibandingkan dengan kedelai impor. 
Faktor tenaga kerja untuk pembuatan tahu di Sumedang bukan masalah, karena mudah diperoleh dan mereka secara tradisional terampil dalam pembuatan tahu. Demikian pula faktor pemasaran tahu di Sumedang bukan masalah sebab setiap tempat yang lokasinya di pinggir jalan langsung menjadi tempat pemasaran tahu.

Berdasarkan hasil wawancara dengan para pedagang dan pembeli tahu, kenyataan sekarang tahu Sumedang ini memiliki rasa yang berbeda - beda karena perbedaan dalam kualitas bahan baku yaitu kacang kedelai, sistim pengolahan, bumbu yang dipakai dan minyak goreng yang digunakan. Menurunnya kualitas tahu Sumedang dapat mengurangi jumlah konsumen, karena itu untuk mempertahankan dan meningkatkan konsumsi masyarakat terhadap tahu Sumedang ini kualitasnya harus tetap dijaga.

\section{Tahu Sebagai Andalan Industri Pangan di Kabupaten Sumedang}

Walaupun industri tahu bukan merupakan industri utama di Kabupaten Sumedang namun di lihat dari jenis industri pangan, perusahaan tahu cukup banyak menyerap tenaga kerja, mulai dari pengusaha, buruh dan para pedagang tahu yang memasarkan langsung kepada para konsumen, karena itu pembuatan tahu menjadi industri yang banyak menyerap tenaga kerja dalam bidang ekonomi non formal di Kabupaten Sumedang.

Berdasarkan data dari Dinas Perindustrian Perdagangan dan Investasi di Kabupaten Sumedang pada tahun 2007 tercatat ada 81 industri tahu. Jumlah industri tahu yang sebenarnya diperkirakan lebih dari 100 buah, terutama karena banyaknya pembuatan tahu sebagai industri rumah tangga (home industry ) yang tidak terdaftar di Dinas Perindustrian.

Tabel Jumlah Industri Tahu Di Kabupaten Sumedang Tahun 2007

\begin{tabular}{|c|c|c|}
\hline NO. & Kecamatan & Jumlah Unit Usaha \\
\hline 1 & Sumedang Selatan & 18 \\
\hline
\end{tabular}




\begin{tabular}{|c|c|c|}
\hline 2 & Sumedang Utara & 32 \\
\hline 3 & Tanjung Sari & 10 \\
\hline 4 & Ganeas & 1 \\
\hline 5 & Pamulihan & 1 \\
\hline 6 & Situraja & 3 \\
\hline 7 & Cisarua & 1 \\
\hline 8 & Cimalaka & 1 \\
\hline 9 & Darmaraja & 4 \\
\hline 10 & Cimanggung & 2 \\
\hline 11 & Conggeang & 3 \\
\hline 12 & Jatinangor & 3 \\
\hline 13 & Cibugel & 1 \\
\hline 14 & Paseh & 81 \\
\hline & Jumlah & \\
\hline
\end{tabular}

Sumber : Disperindag dan Investasi Kabupaten Sumedang

Dari tabel di atas dapat kita lihat dari 14 Kecamatan yang ada di Kab. Sumedang memiliki usaha di bidang industri tahu dan yang paling banyak jumlah industri tahu ini terdapat di 3 kecamatan yaitu Sumedang Utara (32 Unit), Sumedang Selatan (18 Unit) dan Tanjung Sari (10 Unit). Ketiga kecamatan ini lokasinya paling ekonomis untuk daerah pemasaran tahu karena berada pada jalur lalu - lintas Bandung - Cirebon yang padat dengan mobilitas penduduk dan kendaraan bermotor.

\section{Penutup}

Tahu merupakan makanan rakyat yang relatif murah namun memiliki nilai gizi yang tinggi karena kandungan proteinnya lebih dari $40 \%$. Harga tahu Sumedang dewasa ini berkisar antara Rp. 250 sampai Rp. 300 per potong, hal ini bergantung pada ukurannya yang berkisar antara 3 x $3 \mathrm{Cm}$ sampai 4 x $4 \mathrm{Cm}$. Bahkan ada juga yang berukuran 5 x 5 $\mathrm{Cm}$ dengan harga Rp. 500 per potong. Harga ini masih terjangkau oleh pembeli. 
Selera masyarakat akan tahu Sumedang hingga sekarang tidak berubah bahkan konsumennya bertambah, karena setiap wisatawan yang berkunjung ke Sumedang atau orang yang melewati wilayah Sumedang umumnya singgah untuk menyempatkan diri membeli tahu sebagai oleh - oleh. Karena itu agar makanan tahu ini tetap menjadi andalan industri pangan dan industri pariwisata perlu dijaga kualitasnya agar tetap memiliki rasa lezat dan gurih sebab belakangan ini para pedagang tahu Sumedang mulai bermunculan di luar wilayah Sumedang seperti di Cileunyi, Cipacing dan Cicalengka, ternyata rasa tahu di daerah ini tidak selezat tahu Sumedang asli, hal ini dapat menurunkan minat konsumen kepada tahu Sumedang yang sudah disukai masyarakat.

\section{Daftar Pustaka}

Balai Pusat Statistik. 2006. Kabupaten Sumedang Dalam Angka. Sumedang: BPS.

Balai Pusat Statistik. 2006. Sensus Sosial Ekonomi Daerah Kabupaten Sumedang. Sumedang: BPS Kabupaten Sumedang.

Dinas Perindustrian, Perdagangan dan Investasi Kabupaten Sumedang. 2006. Data Produsen Tahu dan Mie Basah di Kabupaten Sumedang.

Djamari. 1979. Aplikasi Prinsip-prinsip Geografi Untuk Orientasi Macam- macam Indistri. Bandung:Ikatan Geografi Indonesia.

Tati Sumiati. 2007. Kondisi Sosial Ekonomi Pengrajin Tahu di Kecamatan Sumedang Utara Kabupaten Sumedang. Bandung: UPI.

Supriatna, Dadang.(2005).Membuat Tahu Sumedang. Jakarta: Penebar Swadaya. 